\title{
Taribavirin Hydrochloride
}

National Cancer Institute

\section{Source}

National Cancer Institute. Taribavirin Hydrochloride. NCI Thesaurus. Code C77929.

A hydrochloride salt form of taribavirin, an orally available prodrug of ribavirin, a synthetic nucleoside analog of ribofuranose with activity ag ainst a wide range of viruses, especially the hepatitis C virus and influenza virus. Taribavirin is converted into ribavirin, which is incorporated into viral nucleic acid, thereby inhibiting viral RNA synthesis, inducing viral genome mutations, and inhibiting normal viral replication. 